\title{
Journal of Intercultural Studies
}

\section{What's Love Got To Do With It? Emotional Authority and State Regulation of Interracial/ national Couples in Ireland}

\section{Rebecca Chiyoko King-O'Riain}

To cite this article: Rebecca Chiyoko King-O'Riain (2018) What's Love Got To Do With It? Emotional Authority and State Regulation of Interracial/national Couples in Ireland, Journal of Intercultural Studies, 39:4, 494-509, DOI: 10.1080/07256868.2018.1484344

To link to this article: https://doi.org/10.1080/07256868.2018.1484344

曲 Published online: 01 Aug 2018.

Submit your article to this journal $₫$

Џ Article views: 80

View Crossmark data $\complement$ 


\title{
What's Love Got To Do With It? Emotional Authority and State Regulation of Interracial/national Couples in Ireland
}

\author{
Rebecca Chiyoko King-O'Riain \\ Maynooth University, Maynooth, County Kildare, Ireland
}

\begin{abstract}
Globalization has increased the mobility of people across national borders and this has increased the number of interracial/national couples where partners do not necessarily have the same races, citizenships, cultures or languages across the globe. When interracial/national couples (both same-sex and heterosexual) try to cross borders to put down family roots, nation states often use emotions and citizenship laws to assert their authority to control the boundaries of the population, worker movement and to protect 'national' culture from multiracialism. Challenges to state authority are increasing and some states respond by trying to exercise control over interracial couples by using emotions in adjudicating and authenticating love in the crackdown on supposed 'sham' interracial/national marriages. States do this through legal and organizational practices to constitute their emotional authority. These processes illustrate collective attitudes towards interracial couples which contain a threat of intimacy that these couples represent to the nation through an examination citizenship laws and the experiences of mixed international couples in the Republic of Ireland as a way to understand the experiences of mixed couples and families within a global context.
\end{abstract}

\section{KEYWORDS}

Mixed couples; interracial couples; multiracialism; biracialism; migration; globalization; nationhood; emotions

\section{Introduction}

Is globalization making the world a smaller, more intimate place, or is it taking us away from those we love? Globalization is changing both the meanings and practices of love as emotions change upon intimate contact with those from different races, ethnicities, and cultures and as states struggle to maintain control as global mobility challenges their ability to determine who can legally love whom. There is tension between the rights of people from different countries to love whom they choose and the right of states to decide who is a citizen through marriage, migration and citizenship laws.

This paper analyses how the Irish state is attempting to control new realms of intimate life, using processes of emotionalization and racialization to extend rights only to those considered as 'racially' within the nation. It develops a documentary analysis of legal norms around 'sham' marriages and qualitative analysis of indicative interviews with couples in the Republic of Ireland. The article proceeds in two steps. First, I briefly 
outline how notions of romantic love are entangled in the founding of the Irish state and cannot be understood without discussions of the nation state, race, citizenship and belonging. Secondly, I then apply D'Aoust's concept of 'technologies of love' (2018) to a literature on the sociology of emotions to show how legally codified emotions trickle down and become embedded in the organizational structures and practices of the Irish state, thus realizing them in everyday life.

States can serve to embed societal attitudes towards interracial mixing (Chito-Childs 2009). States across the globe have, for the most part, done away with formal anti-miscegenation laws. However, I argue that states remain subtly racialized by using emotional authenticity (the 'realness' of love) to question those who marry outside the racial/national norm. In this sense, states link interpersonal and collective understandings of interracial acceptance or denial through their management and adjudication of the emotional life of citizens and their partners. I illustrate how technologies of love translate within the Irish context into a moral economy of suspicion, particularly of interracial couples, and how some of those couples navigated this emotionalized state terrain in Ireland.

\section{The Social Context of State Emotional Authority}

But, as Tina Turner says, 'What's love got to do with it?' Love has everything to do with it because states use their own definitions and understandings of racialized love as a primary technique and rationale to police their borders. The state approves marriages based on 'real love', but when it feels that the partnership might be false or not based on love, typically signified by interracial love, it falls back on its authority to adjudicate love - determine who can love whom and be the expert in determining which love is authentic and which is not. But what criterion does the state use to determine this? Where does it get the emotional authority to do so?

The state is always implicated in the formal legitimation of intimate relationships. As Turner - not Tina - (2008) writes,

... the decision to marry and to reproduce is typically seen to be the result of private, romantic decisions of couples, but the state has a very clear public interest in these private decisions, because the future of the population and the society depends upon them. International marriages complicate this picture ... . (Turner 2008: 45)

The state has an interest in regulating couples because it is trying to control its population growth, racial/cultural integrity and its labour force domestically and the boundaries of the population, racial/cultural dilution and worker movement internationally. As Bonjour and Kraler (2015) state,

Family migration policies are control policies that aim to protect the labour market and the welfare state, but also to 'defend the (imagined) homogeneity and ... cultural cohesion of the nation ... in this sense, family migration policies are symbolic policies, which serve to 'define and mark the (national) norm and identity, and to show that the government upholds and protects this norm and identity'. (Bonjour and de Hart, 2013: 73, 1412)

The interracial/national couple is a possible 'conduit of rights,' (Turner 2008: 46) and the state becomes involved in gatekeeping mixed couples and their mixed-race children in terms of rights, movement and culture from abroad. ${ }^{1}$ This can have significant implications - as Parisi (2015) argues that, 
Debates on intermarriages and convenience marriages ... transform the issue of security/ non-security into a dividing line that runs through families and individuals - through their bodies and their feelings ... the mixed family, on the one side, becomes a border zone through which the state is able to govern the conduct of those who enter and violate the apparent homogeneity, integrity and well-being of the 'national community'. On the other hand, the mixed couple and intimate life define a resistance against the state's bio political power to control people (Parisi 2015: 749-750).

Given these bio political struggles, D'Aoust illustrates how 'emotions such as romantic love can be seen as central to the governmentality of marriage migration' (D'Aoust 2018, 41). As Beck and Beck-Gernsheim state:

... when the basic right to love crosses the frontier, the nation-state's tolerance comes to an end. The traffic lights turn red and the burden of proof shifts the other way. The suspicion of guilt now comes into play. Indeed, cross-border marriage becomes a potential crime. (Beck and Beck-Gernsheim 2014: 176)

Assuming marital racial endogamy as the norm, European states seem to interfere less in the emotional lives of endogamous marriages, presumably because such marriages do not extend citizenship rights to additional persons. However, the state response to mixed marriages is to adjudicate (decide legally) and authenticate (deciding which love is real) love within interracial/national intimate relationship. This is clear evidence of the continuing, albeit more sophisticated, processes of racial formation (Omi and Winant 2001) within state structures and constitutes a racial project of 'legislating for love' (Myrdahl 2010). But how do states do this?

As D’Aoust (2018: 41) explains,

marriage migration management practices ... have entered into the realm of security policy by relying on a moral political economy of suspicion that notably mobilizes what I call 'technologies of love'.

As such, concepts of love become embedded through practices into the state - technologies of love - and become one of the central conceptual devices through which the state gate keeps its cultural and national borders. These are enacted by the gate keepers registrars, clergy, Gardaí (police), etc. - who 'can confirm effective cohabitation of couples being investigated and involves new bureaucratic actors, units and communication channels that create new relational structures of suspicion, informing and policing' (D'Aoust 2018: 51) Mixed couples are particularly subject to scrutiny as nationality and immigration status, 'bodily characteristics, and behaviour get read and interpreted as potential risk factors ... hence that norms concerning love play an implicit, yet central role ... as a conceptual code and criterion of judgement ... '(D'Aoust 2018: 51). In using D'Aoust's (2018) concept of the technologies of love within a moral economy as applied to mixed couples, this allows an illustration of 'how specific emotions can play a role inside governmentality, how they are related to various structures of power that connect with, yet go beyond, interpersonal interactions or organization bureaucratic structures' (D'Aoust 2018: 44).

States are not neutral organizations, but have strong notions of gender (Haney 1996), race (Omi and Winant 2001) and sexuality (Bell and Binnie 2000) embedded within them through their legal and organizational practices. Through these codified ideas and organizational practices, the state has the power to categorize, legitimate and de-legitimate various intimacies (Toyota 2008). They create a hierarchy of plausible loves where, for 
example, long-term, racially endogamous, heterosexual couples with children are given priority over other family forms and types of love (for more on this see: Bonjour and Block 2016).

Max Weber saw the bureaucracy of the state not as a form of 'affective action' but instead as 'rational-legal' legitimation (Allan 2013: 150). Rationality within the bureaucracy of the state was, by definition, not emotional. And yet, we know that the state is deeply involved in regulating emotions through intimacy (Moran 2001) in the judiciary (Bergman Blix and Wettergren 2016) and in state apologies (Weiner 2005). In this sense, the state can 'do emotions' or be an 'emotional state' (Heaney 2016) and can shape processes of emotionalization and racialization. In Weber's terms, they can generate emotional-organizational forms of legitimate domination. The state can contain racialized emotions - emotions within the state - and can 'do emotions' along racial lines - emotion by the state - such as affective jurisprudence (Bandes and Blumenthal 2012) or racialized feeling (Harvey Wingfield 2010). This paper provides one example of the latter through a case study of how the state can position itself as an emotional and racial authority where emotions are legitimated by the state by managing the interracial affairs of the heart in two ways through adjudicating and authenticating love.

These two processes are abundantly clear in the lived experiences of mixed couples when interacting with state apparatuses around their experiences with marriage, migration and citizenship law. Studies of citizenship tend not to focus on emotion or race, yet, in this article, the actual practices of people and the state's logic of emotional regulation, race and love are shown to be deeply entangled.

\section{Why Ireland?}

There is strong evidence that interracial/national couples in Europe are controversial. Thus far, research in Europe has focused on Norway (Myrdahl 2010; Eggebø 2013), Finland (Pellander 2016), United Kingdom (Turner 2015) and Denmark (Fair 2010), but there has been little research on this in smaller European countries, such as the Republic of Ireland. Ireland has experienced both a rapid increase in migration and mobility by Irish people throughout the Celtic Tiger Boom (2004-2008) and a subsequent fleeing of people from Ireland during the Celtic Tiger Bust (2008-2014). Increasing migration has meant that Ireland is one of the fastest changing societies in Europe in terms of ethnic/ racial diversity in the last ten years. In the 2016 Census, 17.3 per cent of the population in Ireland is now non-Irish born (CSO 2017). Emigration and global experience also return to Ireland with 96.91 per cent of the Irish born population in Ireland affirming that they 'had ever lived abroad' in the 2011 Census (CSO 2012). In 2016, this meant an 87 per cent increase in the number of people claiming dual national status in Ireland from 2011 (CSO 2017).

However, the Irish state has recently heightened monitoring of these interracial/ national or mixed (Irish/Non-Irish) intimate relationships (both within the EU and further abroad). In legal terms, the motive for any Irish/3rd country national (non-EU) marriage in Ireland is not legally challengeable as long as there is consent and no law has been broken, i.e. no one was forced or trafficked into marriage under duress, they are underage or married already. However, there is a significant difference between the law and the policies that illustrate the everyday practices of how the law is understood. 
Far from being the 'rational' bureaucratic state that Weber described, the state becomes an active force in adjudicating and authenticating emotions of racially mixed couples, not just EU/Irish couples. This article now proceeds to give a brief history of marriage, migration and citizenship law in Ireland to illustrate how the Irish state today finds itself trying to gate keep the nation (both in terms of its borders and who can be considered to be a citizen). Central to this is the ongoing crackdown on 'sham' marriages in 'Operation Vantage' which, in 2015, raided more than 40 residential and business premises with over 200 Gardaí (Department of Justice, 2015). I then show how the state comes to exercise its power through legal and organizational practices, which form the racialized emotional authority of the state, giving it the power to routinely adjudicate emotions. I then analyse how a few indicative couples have experienced these processes to show the operation of these only partially formalized organizational practices. ${ }^{2}$

\section{The Legal Constitution of the Emotional Authority of the Irish State}

This section discusses the legal changes in Ireland, which created a situation where the state could strengthen its own racialized emotional authority. Two rapid, but parallel, changes have occurred in Ireland recently: (1) the state is actively grappling with determining which/what citizenship or legal residence rights would be attached to marriage and (2) the state is also bedding down a certain definition of marriage with a particular emphasis on who has access to it. Both of these processes are deeply racialized as the state attempts to accomplish this through both legal and organizational means.

In the early decades of the independent state in Ireland, for domestic marriages (between two Irish people and within Ireland), love was not a necessary element for marriage. Often marriages were arranged by a matchmaker for economic benefit and particularly to secure the transfer of land ownership across generations within landowning families (Gray, Geraghty and Ralph 2016: 103). When the inheriting son married, the wife's family paid dowries. The husband often took on the role of household head of an intergenerational household, which often included aging parents. Within Irish marriages, exchange of monies and land titles was more important than love. Marriage was therefore racially endogamous for the most part and primarily a financial, not emotional, relationship in legal terms. The idea that marriage and family served to meet individual emotional needs were not reflected in Irish state policy until the 1960s and 1970s (Fahey 1998). For the Catholic Church in Ireland, marriage was arguably about procreation and only marginally about love. It was a way to regulate sexuality (Inglis 2005). Love didn't come into it until much later and when it did come, it was strongly seen as a proxy for security and stability.

The institutionalization of marriage and ideologies of the family were key in the process of nation-state building in Ireland. We can see this clearly in the evolution of the Irish constitution (1937) particularly in article 41, which aims to protect the family (41.2.1.), works to recognize the contributions of women in the home and ensures economic circumstances do not oblige a mother to work outside the home (41.2.2) (McGowan 2014). From the language of the constitution, it is clear that the 'family' is assumed to be a heterosexual couple, who is legally married, where the woman is a mother and at home, thus embedding traditional notions of the roles of women into law. 


\section{Irish Citizenship for Aliens}

The notion of the family expanded racially when the 1956 Act provided that an 'alien' (read racially, and nationally, Other) woman got automatic citizenship on marriage to an Irish man subject to filing a declaration with the state (http://www.irishstatutebook. ie/eli/1956/act/26/section/8/enacted/en/html).

This was made abundantly clear in 1981, in Somjee v Minister for Justice [1981] ILRM 324 (and others), where the High Court upheld as constitutional a provision that allowed non-white, non-Irish women married to Irish men to acquire citizenship more or less immediately, even though the same provision did not apply to non-Irish men marrying Irish women who had to go through the lengthy naturalization process.

The Court found that the state was entitled to have a diversity of arrangements for male and female 'aliens'. 'The judge, in a curious passage, suggested that the Oireachtas was entitled to take the view that women were less likely to be engaged in the kind of activity that might be relevant in denying citizenship' (Ryan, personal communication, 14 Feb 2016). Perhaps this assumed that non-Irish men were inherently more likely than women to pose a threat to society and state. Non-Irish women were clearly expected to give up culture and take on the name and culture of the Irish husband. They were expected to be more flexible and easier to transfer their fidelity (love) to the nation and loyalty to the state. Both of these ideas racialized the gender status of non-white, non-Irish spouses, embedding racialized notions of patriarchy into state laws.

In proposing new legislation in 1986, the then Minister of State at the Department of Justice, Nuala Fennell (1986), stated:

The position as regards the foreign husbands of Irish women who wish to obtain Irish citizenship is different. In their case the foreign man has no absolute right to Irish citizenship. For him the obtaining of citizenship is through the process of naturalization. To qualify for citizenship under the naturalization process certain conditions must be fulfilled. In the case of the foreign husband of an Irish woman these include two years residence in the State, being of good character and an intention to reside in the State after naturalization.

She went on to state how Irish society and culture had changed in these matters and how the law should reflect the growth of international mixed marriages. She stated:

Our legislators were probably acting on the assumption that in marriages of mixed nationalities the wife was more likely to move to her husband's country than the husband move to her country.

Therefore, in phase two, the 1986 Act provided that both men and women got automatic citizenship after three years, subject to filing a declaration (http://www.irishstatutebook.ie/ eli/1956/act/26/section/8/enacted/en/html).

Changes in gender norms within Ireland prompted this legal and organizational change and while it weakened women's entitlement to citizenship, overall it reduced patriarchal relations.

The Irish Nationality and Citizenship Act 2001, which amended the 1956 Act adding a new section, $15 \mathrm{~A}$, came into force in 2005. This required a marriage lasting three years with one-year continuous residence on the Island of Ireland before the application and in the four years before that a total residence of two years (three years in total). The couple was also required to intend to reside on the Island of Ireland after naturalization 
and have made a declaration of fidelity to the nation. But how was the emotion of fidelity to be measured?

\section{Challenges to the Irish State}

By 2005, gender differences seemed to have disappeared, but the number of cases coming to the courts relating to the fidelity of interracial/national marriages, citizenship and migration were on the rise. The cases of A.A. v. The Minister for Justice, Equality and Law Reform [2005] 4 I.R. 564 and others, broadly established that there is no absolute right to residence in Ireland simply because you are married to an Irish citizen. The state is not obliged to respect a married couple's choice of residence and can deport or refuse entry.

More recently, the focus is shifting to consider that the 'impact on married life' must be considered as a factor in decision-making. In X.A.(a non-white, non-Irish infant suing by her mother and next friend, J.P.A.), J.P.A. and S.O.A. v Minister for Justice Equality \& Law Reform, Ireland and The Attorney General [2011] IEHC 397, it was found that,

The Minister's decision must always respect the essence and substance of the right of the married couple under Article 41. A decision which, in practice, compels the couple to life [sic] more or less permanently apart is, by definition, a very significant interference by the State with a core principle valued and protected by Article $41 \ldots$ it is nonetheless imperative that the respective rights of the applicants and the interests of the State must be fairly weighed by the Minister. (www.supremecourt.ie)

The Irish state was relatively unclear about its migration policy and the state seems to be contracting citizenship rights in response to increased migration. In 2004, the citizenship referendum altered the Irish constitution to change from jus solis to jus sanguinis (right of blood) race/ancestry basis for citizenship. This meant that third generation white Irish Americans who have never set foot in Ireland are 'deserving of citizenship because of ancestry' whereas black Nigerian children who were born in Ireland and have lived in Ireland all their lives (many of whom speak Irish) are not because their parents are not Irish citizens.

Since 2008/2009, immigration policy allows a person married to an Irish citizen to apply for residence in the State. As a matter of policy, de facto partners may also apply for residence if they have been living together for at least two years. This is a matter of policy rather than law, determined by Irish Naturalisation and Immigration Service (INIS) and the Minister for Justice. As with marriage, there is no legal right to residence. This seemed to be a response to address the situation of same-sex couples that were not able to marry or enter into a civil partnership at that time. Bi-national same-sex couples and LGBT campaign groups increasingly raised the issue of immigration as a problem. So while there was no absolute right to residence, the State considered such applications and for the first time, civil partners were treated the same as heterosexual married spouses. The state had then created a new space of organizational authority and adjudication, operating within a deliberately created sphere of legal ambiguity.

It is clear then that the state feels it has a duty, enshrined in the constitution, to support marriage as an institution and the corresponding family but that it is only relatively recently that love became an assumed legal and organizational necessity for marriage. 
In addition, this commitment to support marriage, based on love, may indeed override the state's right to control citizenship based on race.

\section{Contours of Love - the Same-sex Marriage Referendum 2015}

In May 2015, Ireland became the first country in the world to hold a popular vote to approve same-sex marriage adding the phrase 'Marriage may be contracted in accordance with law by two persons without distinction as to their sex' to the constitution. This did away with the civil partnership for same-sex couples and opened the door to their ability to marry. However, racialized migration and citizenship practices, which intersect with marriage laws now also applied to same-sex couples. Before the referendum, same-sex civil partners were treated differently than heterosexual couples because there was really no law to apply to them - their cases were handled subjectively on a case-by-case basis and decided by the Minister for Justice. However, these cases illustrate the tension within the state between the 'right to love' and the concern over the integrity of the immigration system. This reassertion of both policy and the change in law are important because they legally constituted the space for the racialized authentication and adjudication of love - it becomes the rationale for the state to exercise its emotional authority over people of different races who wish to be together.

\section{Organizational Practices of Emotional Authority}

However, these legal spaces are made real through organizational practices. In these practices, the Irish state uses emotions such as love to determine who can bring their non-white, non-Irish partners into the country and who cannot. For example, professionals from outside of the EU (Often from the US, UK and Australia - predominantly racialized white) are automatically entitled to couple reunification and low wage service workers (predominantly people of colour from Asia and Africa) from outside the EU are not. This, in effect, creates hierarchies of love where the love connections of highly educated white migrants are afforded more importance (or legitimacy) than others. Only some couples' love is open to adjudication. But racial profiling of mixed couples became even more apparent in 2014 with the passage of the Civil Registration Act.

\section{Civil Registration Act of 2014}

In August 2015, the Civil Registration (Amendment) Act of 2014 took effect to make entering into a 'sham marriage' more difficult. The act extended the power of registrars (who marry people in registry offices) to question and refuse to perform international marriages, if they suspect it was a 'sham'. But how did they know which marriages to question? Race became the predominant signifier of difference used to target and racially profile mixed couples.

The Department of Justice argued that this legislation was necessary because there were, 'Statistically improbable patterns of marriage, from a cultural and linguistic perspective, notably between women from Eastern Europe and more recently from Portugal, and men from the Indian subcontinent' recorded in Ireland (Minihan 2015). 
The new legislation suggested the criterion for refusing to marry an international couple as:

Having a common language, length of association, how many times they met, residing together, knowing each other's personal details, extent to which they intend to continue an existing commitment to mutual emotional and financial support to each other, and any other information regarding the intended marriage which gives reasonable grounds for considering the marriage to be a marriage of convenience. (Minihan 2015; emphasis added by author)

These criteria are heavily weighted with emotion. They assume that the Irish state is capable of recognizing what a 'commitment to emotional support' is, what it consists of, and how to measure and verify it within in mixed couples.

Under the new legal regime, the organizational focus has sharpened on international mixed couples in Ireland and these processes now lean heavily on definitions of 'true love' and 'real marriages'. More significantly, the Civil Registration Amendment Act of 2014 'for the first time in Irish legal history, made spousal motive relevant to the validity of marriage' (McGowan 2016: 3) as the government tried to dissuade people from coming to Ireland to marry for an 'immigration advantage' under EU free movement rules.

Within this legislation, there was a conflict between allowing for free movement and validating marriage and then citizenship in Ireland.

EU free movers wishing to marry non-EU nationals in Ireland and extend free movement rights to their spouses must therefore undergo a two-stage process of investigation of their relationship. They must first prove to the Civil Registrar that no impediment exists and secondly satisfy the Minister that the marriage is not one of convenience. (McGowan 2016: 5).

Emotion and the existence of love was the primary way that couples prove the latter. However, this law does not apply to marriages involving two Irish people (domestic) or someone from a third (non-EU) country - it only applies to those in the EU. In this instance, motivation for marriage still is not a reason to stop a marriage to gain an immigration advantage. In practice, the way 'suspicious' couples are spotted is through the use of visual cues such as race. Therefore, the targeting of 'sham' marriages within society has meant that all international and interracial couples are questioned on the veracity of their love. Whereas marriage for economic advantage was the norm in the past, it is now not acceptable because it is interracial and international and not monoracial/domestic and is seen as crossing the nation-state divide for immigration advantage.

There are, of course, some people who engage in 'sham marriage' solely for migration purposes. The most sensational recent case was that of an Asian trainee Garda (policeman) who married a lesbian woman from Eastern Europe in Ireland in order to gain the right to live and work in Ireland (Lally 2018). However, the myth that all international mixed couples are abusing the law, creates a racialized disbelief and suspicion of all mixed couples - a moral economy of suspicion based on race (D'Aoust 2018). The change in Irish law and organizational practices makes all Irish citizen/non-citizen international couples live under the shadow of disbelief and suspicion regardless of their migration status. For some, even though the motivation for their marriage is not legally challengeable, their credibility within the law and society is increasingly questioned.

Even when the INIS decides to deport individuals they feel are involved in marriages of convenience, family status advantages some in their deportation appeals and not others 
because they are in love. People married and/or with children are seen as more settled, more emotionally attached to the place and therefore less likely to be deported because tearing them away from those they 'love and who love them' is seen as cruel. This assumes a notion of love that is commonly defined and shared within society. It assumes that state actors deporting or refusing to marry, can recognize 'real love' and then can make judgments and adjudicate based on that. Those who are interracially married with real love ties are seen as more culturally integrated with Irish society and therefore more likely to be good citizens, not just in legal terms, but better social citizens. But, intermarriage does not always guarantee the acculturation and acceptance of the nonIrish spouse or their mixed-race children within Irish society (Van Nguyen 2017).

Race signifies a difference in these mixed couples and the state acts on this often visual difference by using the law and emotion to exercise its power, with the law is its main tool and emotion is its measuring stick. Migration, citizenship and marriage laws together form a transnational legal framework or web of laws that form a racialized semi-hard structure, which shapes which emotions people can and should have and creates hierarchies of plausible love. These are embedded in the new law for registrars' as part of their organizational routine as well as the occupational cultures of immigration officers and the Gardaí.

\section{Practices of State Emotionalized Authority}

The brief conversations with couples below illustrate how some international mixed couples in Ireland experience and struggle against the legislation and organizational practices cited above. States seek to limit them through an emotional capital transfer where couples are losing emotional currency when the state will not recognize the veracity of their love. This is highlighted when international mixed couples seek to transport their love across state/nation borders. But even when they successfully transport their coupledom/love across the border into Ireland, there are social and cultural inequalities in the state system of emotional adjudication. Heteronormative and pro-procreative biases in law and state structures are not new ideas, but what is new is that this is cast in emotional terms.

\section{Adjudicating Love}

The state claims it knows what love is. It can adjudicate (decide legally) the difference between 'real' love and 'sham' love (authenticating love) and can exercise power and authority over social actors because of its purported ability to discern true emotions. This authority is exercised over racially mixed international couples even those who marry and migrate legally. For same-sex couples before 2015, this was a particularly strong factor in their migration decisions. The case below of Chris and his partner illustrates how couples often made decisions with the state in mind. Chris, originally from Malaysia and in a same-sex couple, met his Irish partner in Canada. He talked nervously about his migration to Ireland in 2009:

We were really quite naive because we thought when we came here I wouldn't have an issue because we lived together in Canada, we thought, like in the UK, to prove that we lived together that they would allow me to stay. But the response that we got from the government bodies that we contacted was, 'we don't have rules for you people' ... So basically I came in on a student visa because I wanted to resume my studies because I left school when I was 17, so 
that was fine for the first year. And then obviously panic stations, oh my God there is no allowances for same sex couples so what do we do? So I said, ok I have to find a work permit. So fortunately I was working for a recruitment agency, I was doing my qualifications in human resources so they said, look when you finish your course you can join us as a receptionist, even though it is one day a week and what not, and it really ended up being that way here, which was fantastic, so I was quite blessed. So I had a work permit, so that was fine, but I still didn't like the insecurity of it and also I just thought it wasn't right, I am not any problem, I am here because of my partner.

For Chris, the legal recognition was important to himself and his partner, not only for benefits, but also for emotional reasons. He explains,

Because that is really the most human issue in relation to civil partnership and gay marriage because, yeah ok tax credits and inheritance, but here you are stopping two individuals from actually being together. I was shocked to find how many couples there were, not just in Ireland but also all over the world. I heard about a couple in the US, where one partner was Irish and one partner was from somewhere else... they couldn't come back to Ireland. Even though they wanted to come back, they couldn't come back because their partner wouldn't get any status here.

Chris was concerned about the lengthy and inconvenient process of having to stand in line for days to get the visa, he deemed it 'too much of a hassle'. Instead, he had the resources to come in as a student initially and then regularize his migration status afterwards. What mattered was not that he and his partner had lived in Canada as a legal couple, but that he had a Malaysian passport/citizenship. In Canada, that image of Ireland as being open to those who wish to come and visit or live is cultivated by the Irish state but only for those with Irish ancestry offering certificates of Irish ancestry (read white) or an Irish passport for those who can prove they have an Irish grandparent. This process of recruiting those with even remote Irish ancestry distils Irishness into whiteness and perpetuates jus sanguinis (blood) notions of the Irish nation, diaspora and citizenship (KingO'Riain 2007). The fear of the legal rejection of their coupledom drove Chris and his partner's migration choice - adjudication had direct impact of their love lives.

Chris' experience was common in the interviews. The reinvocation of the Irish emigrant who was living in exile in the past who couldn't come home to Ireland due to financial or migration reasons (being undocumented in the non-Irish country) has now become the Irish in exile who can't return home because of whom they love. As Dil Wickremasinghe, a Sri Lankan journalist in Ireland, put it 'How is it that the Government can dictate who you can and cannot fall in love with?' (18 March 2010). In citizenship law, we see racialized determination of who can belong to the Irish nation and who cannot within love. ${ }^{3}$

\section{Authenticating Love}

The state purports to know and be able to authenticate, which love is 'real' and which love is 'fake' in mixed couples. Authenticity tests of the realness of love imply that the state has a set notion of what love is, what constitutes real love, and how they can measure and enforce that definition in its populace. In other words, states get nosey - pushing into the intimate lives of interracial couples, demanding a genealogy of their love and relationship, including intimate details of their (and their children's) lives - details that they do not ask of domestic, monoracial couples. 
In Ireland, the crack down on sham marriages has clearly targeted people of colour and countries of origin that are suspect such as countries in Asia and Africa due to racial visibility. Ireland had been deporting non-EU spouses of EU citizens residing in Ireland and told to stop when the European Court of Justice ruled in 2007 that it was illegal and barred Ireland from doing so. After 2007, EU citizens could live in Ireland with their non-EU spouse, but Irish citizens could only do this at the discretion of the Irish State (Minister for Justice) until the Registrar's Act of 2014. The outcome has created a fragmented and unpredictable system.

This fragmentation has trickled down and made international couples defensive about how they met and their motivation to marry. Sau Ling, a Chinese woman, explains why she and Colum, her Irish husband, got married quickly in the US where they were students, with no family with them, before they moved to Ireland for Colum to take up a new job here. She explains,

Yes, if we weren't moving here I don't know whether we would have gotten married quite so quickly. I think I had always ... I had never been against marriage, whereas Colum was very, oh I don't know about marriage. But because of this legal requirement was there, he started ... he wasn't against it so much then.

The state clearly had an effect on Sau Ling and Colum's decision to elope and get married before migrating to allow her entry into Ireland, but even when interracial couples are legitimately married, they still face racial and ethnic profiling in within the clamp down on sham marriages. It was almost as if every 'sham marriage' by definition was interracial and conversely every interracial marriage was a 'sham'. Sau Ling went on to complain that she continues to be hassled by the state that has asked her every 12 weeks for years to verify whether she is working and residing in Ireland as a condition of receiving child benefit for her three children. This verification process was much less frequent, if ever, conducted with Irish women. ${ }^{4}$

The spectre of being accused of not really being in love, not being a real couple and not belonging to Ireland, hung over many that we interviewed. An Irish man explains how it was for he and his Russian wife:

We met in Croatia for the first time in 2003. It was one of the few places we both could go without a visa (he Irish, she Russian). She couldn't get here (Ireland) without a huge amount of work as it transpired. (Italics added by author)

Within the crackdown though, real love marriages became the collateral damage with some facing the deportations of their spouses (children's father). For example, Gillian Olabode, from county Westmeath, faced this experience in March 2010. Gillian's husband, Henry, was deported to Nigeria as a part of the Department of Justice's campaigning against 'marriages of convenience' - marriages which in actual fact are weirdly inconvenient to accomplish as one must file papers, hire lawyers to get married, then be accused of being fake and not in love, and have your spouse deported. Henry had applied for asylum when he entered the country in 2007 but was unsuccessful in his application. He applied to have his deportation order revoked because he was now married to an Irish citizen and residing in Ireland. Gillian was quoted as saying, 'It is like I don't exist as his wife. As a normal Irish person, his wife would be acknowledged' (Kelly 2010). She went on to say that is was disgraceful that spouses of Irish citizens from outside of the EU were being targeted for deportation while the non-EU spouses of other EU nationals could not be deported. 
Henry had duly informed the state of his marriage to Gillian, an Irish citizen, in 2009. Gillian pointed out that gay couples have more rights than she and Henry and that she was just asking for 'fair play'. She implored the Irish state: 'Bring him (Henry) back, he doesn't want handouts, he wants to work and support his family' (Kelly 2010). This process clearly brings in subjective (and heavily racialized) judgments on behalf of the state to suspect interracial couples and to assume they are not 'really' in love. States are reaching into the most private and intimate emotional parts of interracial couples lives and telling them who has the right to love, who they can love and who they can and can't love authentically or legitimately.

\section{Conclusion}

This paper has revealed and analysed the processes of adjudication and authentication of love through the legal and organizational practices of the Irish state. It has employed a documentary, legal analysis alongside interviews with interracial couples about their experiences with those marriage, migration and citizenship laws. It has illustrated how the state targets interracial/national couples and then decides legally (adjudicates) who can love whom through an authentication of emotion - creating technologies of love within a moral economy of suspicion based in large part upon understandings of race (D'Aoust, 2014). It is clear how international interracial couples are shaped by notions of race, patriarchy and gender through marriage, and with the state through negotiating marriage, migration and citizenship laws.

The differential treatment of alien spouses by gender was eliminated as gender norms changed. Ireland's vote to allow same-sex marriage has altered eligibility for citizenship as well as meanings of family. In the wake of these changes, the effort to evaluate love is relevant in terms of setting the boundaries of citizenship. In truth, there is no way to directly measure the subjective emotion of love, and the state comes to rely on a number of proxies. However, why are these equated with love?

They are equated with love because love holds sway both within a societal definition of love and within an emotion that fits with state logic (in the constitution and in law), which give authority to control the private emotional sphere of people's lives.

By looking at how the Irish state manages affairs of the heart, we saw how the state acts in order to legitimate (heterosexual couples, but only if they are legally married), adjudicate (same-sex couples) and authenticate ('sham' marriages, particularly targeting people of colour) notions of love. In an increasingly transnational world, static and exclusionary (emigrant focused) citizenship policies will not benefit states in the long term. However, reconstructing citizenship and national identity in an era of transnational citizenship under globalization (King-O'Riain et al. 2014) may mean recognizing the racial, cultural and national hybridity present in the emotional practices of international/interracial families in Ireland today.

\section{Notes}

1. I use the terms interracial/national and mixed to mean couples (both same-sex and heterosexual) who define themselves as interethnic, interracial, international, interfaith or multilingual (or sometimes they are all of these!). 
2. These experiences are taken from interviews done for a larger project entitled, 'The Globalization of Love,' based on 36 interviews done with mixed couples in Ireland. All couples had one member who described him/herself as international and not Irish and half of those considered themselves 'not white'. Most of the interviewees were self-identified as middle class with two families identifying as 'well off. Four families described themselves as 'struggling' and seemed to be less well-off.

3. Irishness has long been 'accomplished' whiteness, i.e. the Irish were racialized as almost black at one historical point (1860s in the US), but 'became white' over time. For more on this see Garner (2003), Ignatiev (2008) and Roediger (1999).

4. I have also experienced this first-hand and have been questioned repeatedly and asked to 'prove' employment status, children's residency status and permanent residency status in order to receive child benefit in Ireland because I am a non-Irish national mother, even though I am an Irish citizen.

\section{Disclosure statement}

No potential conflict of interest was reported by the author.

\section{Notes on contributor}

Dr Rebecca Chiyoko King-O'Riain is a Senior Lecturer in Sociology at Maynooth University. Her research interests are in Asian/Asian American popular culture; people of mixed descent, critical mixed-race studies; race/ethnicity, beauty and Japanese Americans; emotions, technology and globalization. She has published in Global Networks, Ethnicities, Sociology Compass, Journal of Asian American Studies, Amerasia Journal, Irish Geography, Sociological Research Online and in many edited books. She is the lead editor of Global Mixed Race (New York University Press). Her book Pure Beauty: Judging Race in Japanese American Beauty Pageants (University of Minnesota Press) examined the use of blood quantum rules in Japanese American Beauty Pageants. Her current research explores globalized interpersonal and interactive forms of bodily culture through skin altering practices in Asia and Europe, beauty pageants and Asian popular culture (Korean and Japanese dramas).

\section{References}

Allan, K., 2013. Explorations in Classical Sociological Theory: Seeing the Social World. 3rd ed. London: Sage.

Bandes, S. and Blumenthal, J., 2012. Emotion and the Law. Annual Review of Law and Social Science, 8, 161-181.

Beck, U. and Beck-Gernsheim, E., 2014. Distant Love. Cambridge: Polity Press.

Bell, D. and Binnie, J., 2000. The Sexual Citizen: Queer Politics and Beyond. Cambridge: Polity Press. Bergman Blix, S. and Wettergren, $\AA$, 2016. A Sociological Perspective on Emotions in the Judiciary. Emotion Review, 8 (1), 32-37.

Bonjour, S. and Block, L., 2016. Ethnicizing Citizenship, Questioning Membership. Explaining the Decreasing Family Migration Rights of Citizens in Europe. Citizenship Studies, 20 (6-7), 779794.

Bonjour, S. and DeHart, B., 2013. A Proper Wife, a Proper Marriage: Constructions of 'us' and 'Them' in Dutch Family Migration Policy. European Journal of Women's Studies, 20, 61-76.

Bonjour, S. and Kraler, A., 2015. Introduction: Family Migration as an Integration Issue? Policy Perspectives and Academic Insights. Journal of Family Issues, 36 (11), 1407-1432.

Central Statistics Office (CSO). 2012. This is Ireland - Highlights from Census 2011 Dublin, Ireland, 32. Available from: http://www.cso.ie/en/media/csoie/census/documents/census2011pdr/ Census,2011,Highlights,Part,1,web,72dpi.pdf. 
Central Statistics Office (CSO). 2017. Census 2016 Summary Results Part I. April, 2016. Available from: http://www.cso.ie/en/media/csoie/newsevents/documents/census2016summaryresultspart1/ Census2016SummaryPart1.pdf [Accessed 9 May 2018].

Chito-Childs, E., 2009. Fade to Black and White: Interracial Images in Popular Culture. Lanham, MD: Rowman and Littlefield.

D’Aoust, A.-M., 2014. Love as Project of (Im)mobility: Love, Sovereignty and Governmentality in Marriage Migration Management Practices. Global Society, 28, 317-335.

D’Aoust, A.-M., 2018. A Moral Economy of Suspicion: Love and Marriage Migration Management Practices in the United Kingdom. Environment and Planning D: Society and Space, 36 (1), 40-59.

Department of Justice and Equality. 2015. Garda Operation Vantage Targeting Sham Marriages and Illegal Immigration. 25 November 2015.

Eggebø, H., 2013. A Real Marriage? Applying for Marriage Migration to Norway. Journal of Ethnic and Migration Studies, 39 (5), 773-789.

Fahey, T. 1998. Family Policy in Ireland, a Strategic Overview-an Abstract of a Report to The Commission on the Family by Tony Fahey, ESRI. In: Strengthening Families for Life - Final Report to the Minister for Social, Community \& Family Affairs. Dublin: Government Publications.

Fair, L.S., 2010. 'Why Can't I get Married?' - Denmark and the 'Twenty-four Year Law'. Social and Cultural Geography, 11 (2), 139-153.

Fennell, N. 1986. The Minister of State at the Department of Justice (Mrs. Fennell) in a Seanad Éireann Debate, Vol. 113 No. 10, Tuesday, 24 June. Available from: http://oireachtasdebates. oireachtas.ie/debatespercent20authoring/debateswebpack.nsf/takes/seanad1986062400007? opendocument.

Garner, S., 2003. Racialization in the Irish Experience. London: Pluto.

Gray, J., Geraghty, R., and Ralph, D., 2016. Family Rhythms: The Changing Textures of Family Life in Ireland. Manchester: Manchester University Press.

Haney, L., 1996. Homeboys, Babies, Men in Suits: The Statelet and the Reproduction of Male Dominance. American Sociological Review, 61 (5), 759-778. Available from: http://www.jstor. org/stable/2096452.

Harvey Wingfield, A., 2010. Are Some Emotions Marked "Whites Only"? Racialized Feeling Rules in Professional Workplaces. Social Problems, 57 (2), 251-268.

Heaney, J. 2016. State, Power, and Emotions: Towards the Emotional State. Paper presented at the University College Dublin Sociology Seminar, Dublin, Ireland. 21 September.

Ignatiev, N., 2008. How the Irish Became White. New York, NY: Routledge.

Inglis, T., 2005. Origins and Legacies of Irish Prudery: Sexuality and Social Control in Modern Ireland. Eire-Ireland, 40 (3\&4), 9-37. doi:10.1353/eir.2005.0022.

Kelly, T. 2010. Five Month on and Little Progress for Gillian. Westmeath Independent, 11 August. Available from: http://www.westmeathindependent.ie//news/roundup/articles/2010/08/11/3999274five-months-on-and-little-progress-for-gillian/print.

King-O’Riain, R.C., 2007. Counting on the Celtic Tiger: Adding Ethnic Census Categories in the Republic of Ireland. Ethnicities, 7 (4), 516-542. doi:10.1177/1468796807084015.

King-O’Riain, R.C., et al., 2014. Global Mixed Race. New York: New York University Press.

Lally, C. 2018. Trainee Garda Married Gay Woman in Sham Marriage for €15,000. Irish Times, 24 April. Available from: https://www.irishtimes.com/news/crime-and-law/trainee-garda-marriedgay-woman-in-sham-marriage-for-15-000-1.3472798.

McGowan, D. 2014. The Normalising Power of Marriage Law: An Irish Genealogy, 1945-2010. Thesis (PhD). Maynooth University.

McGowan, D., 2016. Impeding Free Movement with Marriage Law: The Civil Registration Act 2014. Irish Journal of Family Law, 19 (2), 3-7.

Minihan, M. 2015. 'Sham Marriages' to be Targeted by New Legislation. Irish Times, 18 August. Available from: http://www.irishtimes.com/news/politics/sham-marriages-to-be-targeted-bynew-legislation-1.2320881.

Moran, R.F., 2001. Interracial Intimacy: The Regulation of Race and Romance. Chicago, IL: University of Chicago Press. 
Myrdahl, E.M., 2010. Legislating Love: Norwegian Family Reunification law as a Racial Project. Social and Cultural Geography, 11 (2), 103-116.

Omi, M., and Winant, H., 2001. Racial Formation. London: Routledge.

Parisi, R., 2015. Practices and Rhetoric of Migrants' Social Exclusion in Italy: Intermarriage, Work and Citizenship as Devices for the Production of Social Inequalities. Identities: Global Studies in Culture and Power, 22 (6), 739-756.

Pellander, S. 2016. Gatekeepers of the Family: Regulating Family Migration to Finland. Academic dissertation. University of Helsinki.

Roediger, D., 1999. The Wages of Whiteness. New York, NY: Verso Books.

Toyota, M., 2008. Editorial Introduction: International Marriage, Rights and the State in East and Southeast Asia. Citizenship Studies, 12 (1), 1-7. doi:10.1080/13621020701794083.

Turner, B.S., 2008. Citizenship, Reproduction and the State: International Marriage and Human Rights. Citizenship Studies, 12 (1), 45-54.

Turner, J., 2015. The Family Migration Visa in the History of Marriage Restrictions: Postcolonial Relations and the UK Border. The British Journal of Politics and International Relations, 17, 623-643.

Van Nguyen, D. 2017. They Called Her a $\mathrm{N}^{* * \star}$ ger Lover: Ireland's Interracial Couples. Irish Times, 20 May. Available from: http://www.irishtimes.com/life-and-style/people/they-called-her-a-ner-lover-ireland-s-interracial-couples-1.3087824 [Accessed 21 May 2017].

Weiner, B., 2005. Sins of the Parents: The Politics of National Apologies in the US. Philadelphia, PA: Temple University Press.

Wickremasinghe, D. 2010. Love Migrants. Available from: https://dilw.wordpress.com/2010/03/18/ love-migrants/. 